STATE OF WASHINGTON

DEPARTMENT OF INATURAL RESOURCES

Brian Boyle, Comm issioner of Public Lands

Art Stearns, Supervisor

DIVISION OF GEOLOGY' AND EARTH RESOURCES

Raymond Lasmunis, State Geologist

GEOPHYSICAL MAP GM-27

\title{
COMPLETE BOUGUER GRAVITY ANOMALY MAP, CASCADE MOUNTAINS, WASHINGTON
}

By

Z.F. DANEŠ ANL) W.M. PHILLIPS

Prepared in cooperation with

U.S. Department of Energy

Contract DE-AC(13-79ET27014

\section{3}




\section{DISCLAIMER}

This report was prepared as an account of work sponsored by an agency of the United States Government. Neither the United States Government nor any agency Thereof, nor any of their employees, makes any warranty, express or implied, or assumes any legal liability or responsibility for the accuracy, completeness, or usefulness of any information, apparatus, product, or process disclosed, or represents that its use would not infringe privately owned rights. Reference herein to any specific commercial product, process, or service by trade name, trademark, manufacturer, or otherwise does not necessarily constitute or imply its endorsement, recommendation, or favoring by the United States Government or any agency thereof. The views and opinions of authors expressed herein do not necessarily state or reflect those of the United States Government or any agency thereof. 


\section{DISCLAIMER}

Portions of this document may be illegible in electronic image products. Images are produced from the best available original document. 


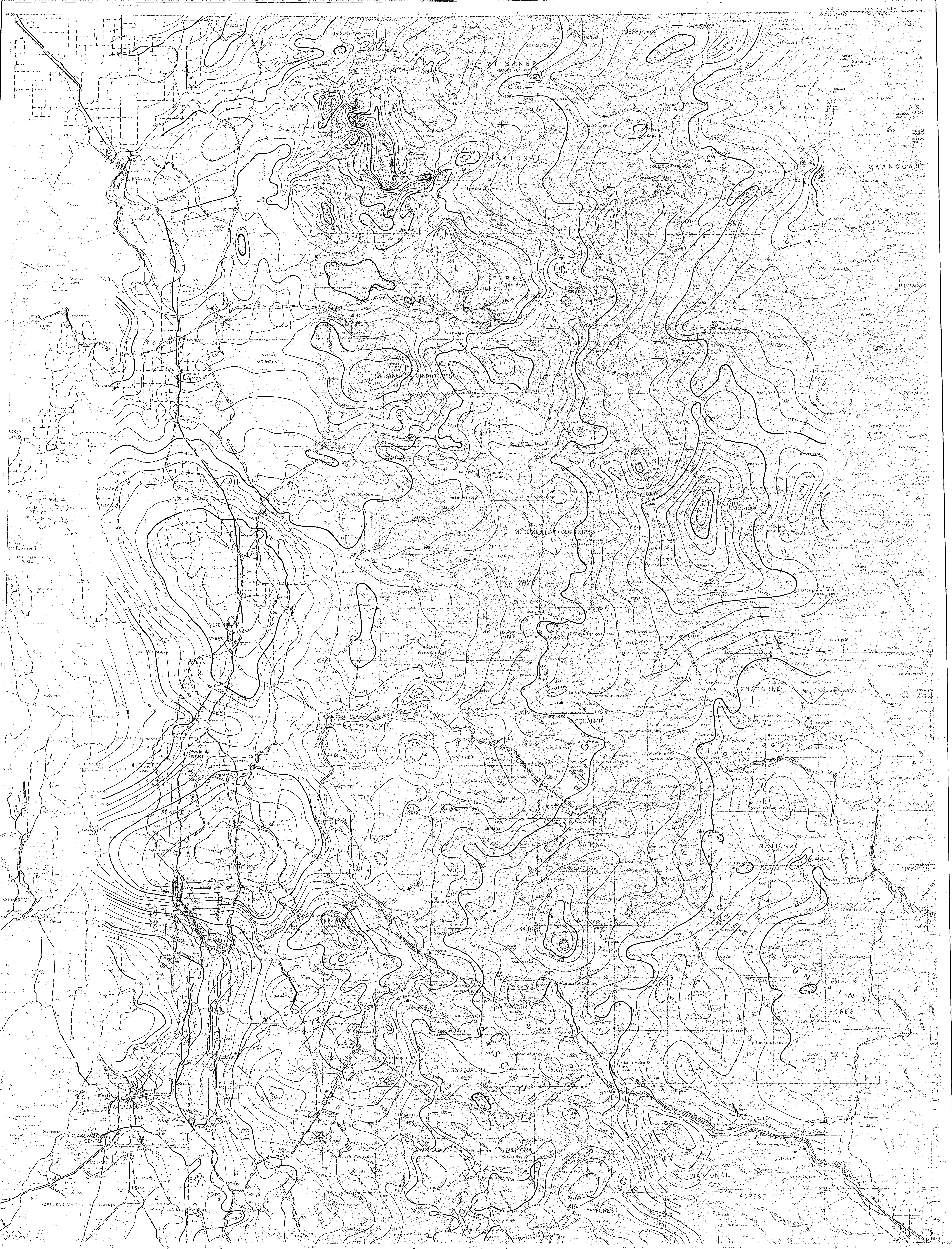



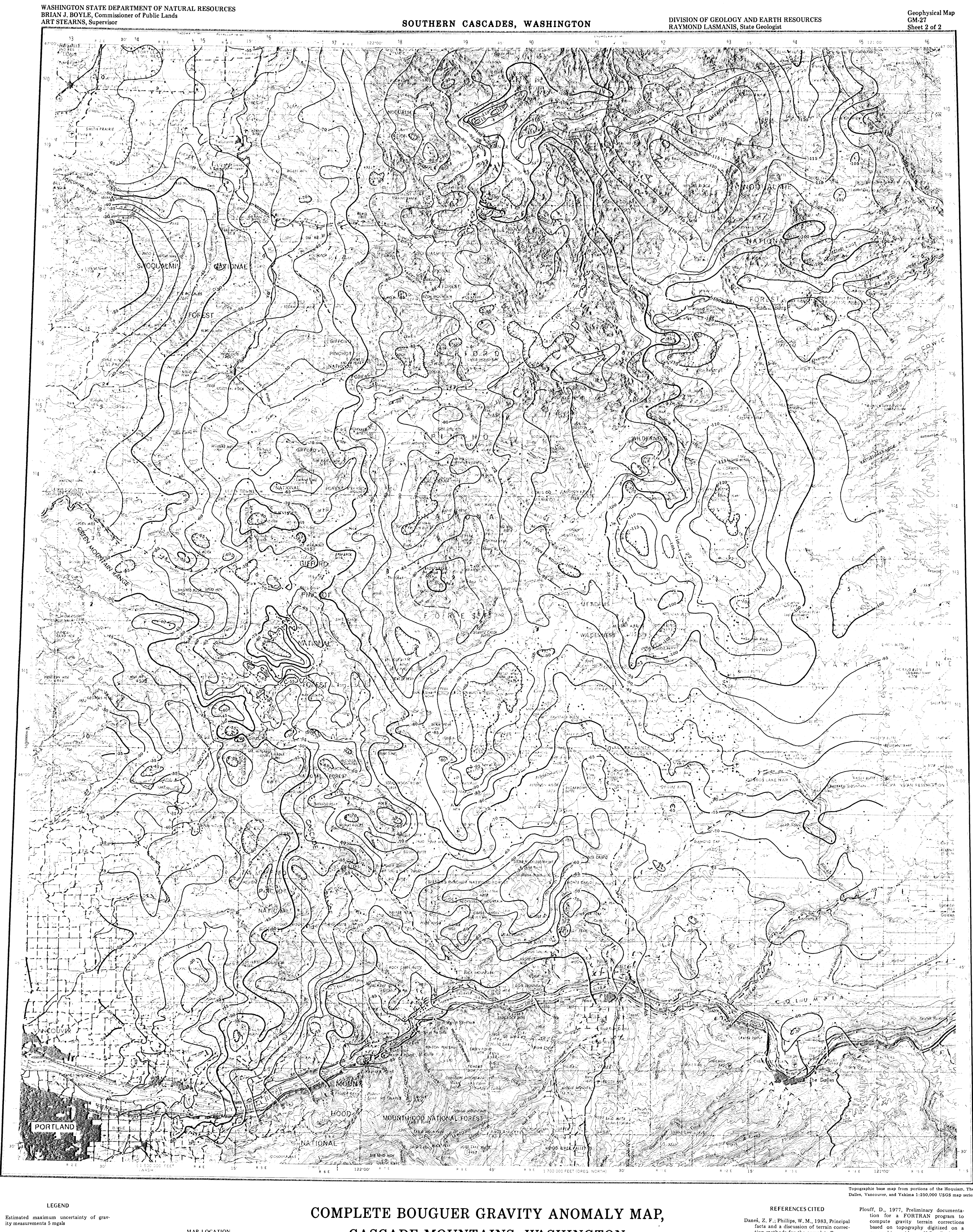

COMPLETE BOUGUER GRAVITY ANOMALY MAP,

CASCADE MOUNTAINS, WASHINGTON
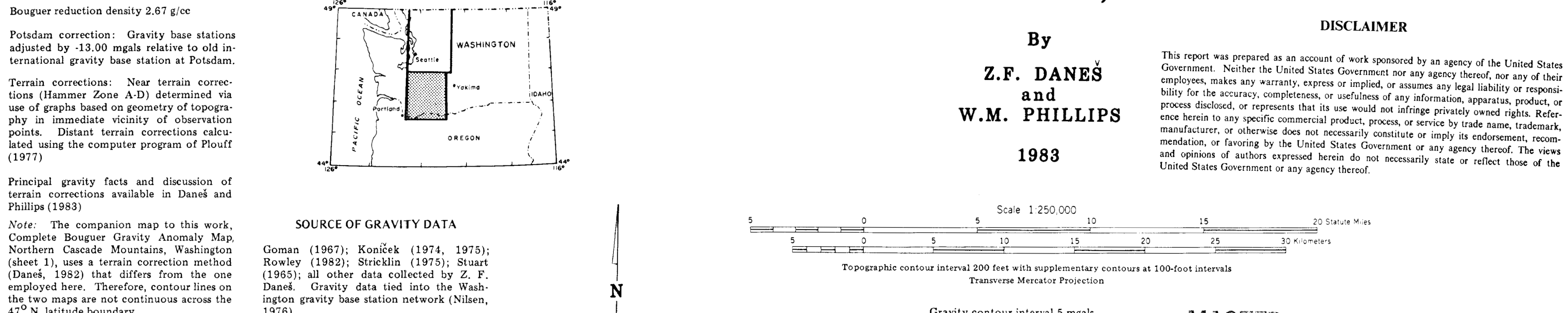